\title{
Effect of exposure to petroleum hydrocarbons upon cardio-respiratory function in the common sole (Solea solea)
}

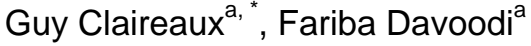 \\ ${ }^{a}$ Centre de Recherche sur les Ecosystème Marin et Aquacole (CNRS/IFREMER), Place du Séminaire, 17137 \\ L'Houmeau, France \\ *: Corresponding author: Guy Claireaux, Tel.: +33 2980169 29; fax: +33 2980163 11, email address : \\ guy.claireaux@univ-brest.fr
}

\begin{abstract}
:
The long term consequences of oil exposure upon marine populations are still poorly evaluated. One particular missing piece of information relates to the link between oil exposure, individuals' ability to face environmental contingencies and populations' production and dynamics. In that context, the present paper investigates the impact of oil exposure upon fish cardio-respiratory performance, this performance being viewed as a key determinant of individual fitness. Experimental conditions replicated the contamination conditions observed during the weeks that immediately followed the Erika oil spill (west coast of France; December 1999). Sole (Solea solea), were exposed to number-2 oil for 5 days and were then challenged with an acute rise in temperature (from 15 to $30^{\circ} \mathrm{C}$ at $1.5^{\circ} \mathrm{C} \mathrm{h}^{-1}$ ). Oxygen consumption, cardiac output, heart rate and stroke volume were monitored throughout. Experimental results showed that compared to uncontaminated control animals, oil-exposed sole displayed impaired cardio-respiratory responses and were unable to meet the temperature-driven increase in tissues oxygen demand. The relationship between oxygen consumption and cardiac output indicated that oil-exposed fish had recourse to venous oxygen stores very early in the thermal challenge $\left(20^{\circ} \mathrm{C}\right)$. In control fish there was no evidence for depletion of venous oxygen store until above $25^{\circ} \mathrm{C}$.
\end{abstract}

Keywords: Petroleum hydrocarbons; Temperature; Oxygen consumption; Cardiac performance; Environmental adaptation; Solea solea 


\section{Introduction}

Coastal areas are particularly susceptible to accidental pollution by anthropogenic pollutants and in particular by petroleum hydrocarbons (Halpern et al., 2008). As far back as in the 1970s it was estimated that 6 to 7 million tons of hydrocarbons were introduced into marine ecosystems every year (Clark and MacLeod, 1977). Since then increased awareness of environmental issues has been paralleled by the development of a large range of instruments and methodologies designed to assess the consequences of these pollutions. A rapid review of these tools readily shows, however, that it is the socioeconomic cost of a discharge which is the most appropriately assessed while its ecological impact remains poorly grasped (Hay and Treyer 2006; Hay and Thébaud, 2006).

It is generally accepted that there is a link between the capacity an organism to face natural challenges and its ability to survive, grow and reproduce. However, despite the intuitive appeal of this proposal very little evidence has been collected in support of it. In 1999 the sinking of the oil tanker Erika off the western coast of France provided an opportunity to shed a new light on the link between environmental adaptation ability and fitness in fish. Following the spill, a large range of field surveys was initiated to monitor the evolution of the contamination and its impact upon organisms and habitats. For economical and ecological reasons the common sole (Solea solea) was selected as a model species to examine the effects of oil exposure upon fish populations (For more details about the accident and the research programs that ensued, readers may refer to the special issue of Aquat. Living Resour. 17, 2004). Two field observations particularly attracted the attention of the scientific community in charge of this monitoring. Field surveys indeed revealed that during the 10 months that followed the spill, young sole were still abundant on the impacted nurseries and that fish 
condition factor was not significantly different from that of previous years (Claireaux et al., 2004). Two years later, however, stock assessment data showed that the 1999 cohort (2group) had experienced poor survival, the size of that year-class being $40 \%$ lower than expected (ICES Advisory Committee on Fishery Management, http://www.ices.dk; data reproduced in Davoodi and Claireaux, 2007).

With this information as a background, we initiated a series of experiments aimed at testing the hypothesis that hydrocarbon exposure affected the dynamics of juvenile sole population via impaired capacity of individuals to face natural contingencies. A first set of experiments consisted in exploring the link between fuel exposure and fitness using semi natural tidal earthen ponds as mesocosms. These population-level experiments confirmed that exposure to petroleum hydrocarbon durably affected the ability of sole to cope with environmental constraints. Six month after having been acutely exposed to heavy fuel, experimental populations presented lower survival, impaired growth and reduced capacity to face interspecific competition (Claireaux et al., 2004; Gilliers et al., 2009). To uncover the physiological basis of this lessened ability for environmental adaptation, a second series of experiments examined the influence of fuel exposure upon sole energetics. This study revealed that compared to control fish, fuel-exposed sole had reduced scope for aerobic activity as well as markedly depressed tolerance to decreased oxygen availability (hypoxia). The critical oxygen concentration (the minimum oxygenation level required to sustain standard metabolic rate) was $2.5 \mathrm{mg} \mathrm{l}^{-1}$ in the fuel exposed fish and $4.1 \mathrm{mg}^{-1}$ in the control unexposed fish. On the other hand, standard metabolic rates (SMR) in control and contaminated fish were comparable (39.2 and $31.6 \mathrm{mg} \mathrm{O}_{2} \mathrm{~kg}^{-1} \mathrm{~h}^{-1}$ respectively; Davoodi and Claireaux, 2007). 
1 In a given set of environmental conditions, the ability of an organism to obtain and dissipate energy is intimately linked to the ability of the cardio-vascular system to provide tissues with the required amount of oxygen and nutrients (Lotka, 1922; Farrell, 2007). Yet, very few studies have actually examined the influence of hydrocarbon exposure upon cardiorespiratory performance. Published reports document links between hydrocarbon exposure and myocardium morphological abnormalities and pericardial oedema in herring embryos (Clupea harengus; Middaugh et al., 1998; Marty et al., 1997; Carls et al., 1999), rainbow trout (Oncorhynchus mykiss; Walker et al., 1991) and zebrafish (Danio rerio; Henry et al., 1997). Reduced routine heart rate have also been reported in herring embryos (Middaugh et al., 1998; Vines et al., 2000), zebrafish (Henry, 1997), sheephead minnow (Cyprinodon variegatus) and mummichog (Fundulus heteroclitus; Anderson et al., 1977). More recently, Incardona et al. (2004) reported that defects in cardiac function preceded morphological abnormalities in zebrafish (Danio rerio) embryos exposed to polycyclic aromatic hydrocarbons (PAH). Even more recently, Incardona et al., (2009) confirmed these cardiotoxic effects of PAH in embryonic Pacific herring (Clupea pallasi). These authors also reported a dose-dependent alteration of heart rate and rhythm and, more importantly, suggested that these alterations resulted from direct effects of PAH upon physiological targets in the heart rather than being the indirect consequences of developmental defects caused by the exposure to PAH.

To examine whether the reduction in environmental adaptation ability of oil-exposed sole could have a cardiotoxic origin we compared the cardio-respiratory performance of control and oil-exposed individuals. To conduct this comparison we designed a temperature challenge test which was largely inspired by the protocol of Gollock et al., (2006). In their experiment, Gollock and coworkers examined how Atlantic cod (Gadus morhua) oxygen uptake at the 
1 gills and distribution by the cardiovascular system was adjusted to match rising tissue oxygen

2 during an acute temperature increase (approx $10{ }^{\circ} \mathrm{C}$ at $1.7{ }^{\circ} \mathrm{C} \mathrm{h}^{-1}$ ). Sole were captured from uncontaminated sites and experimentally exposed during 5 days to contamination conditions that mimicked those encountered during the weeks that followed the ERIKA spillage. Following a 24-hour recovery period, fish were fitted with a Transonic ${ }^{\circledR}$ flow probe and placed in a respirometer. Following a second recovery period, cardiac variables and oxygen consumption were measured as water temperature was raised from $15{ }^{\circ} \mathrm{C}$ (acclimation temperature) to $30{ }^{\circ} \mathrm{C}$ at a rate of $1.5{ }^{\circ} \mathrm{C} \mathrm{h}^{-1}$. Cardio-respiratory responses were then compared to those of an uncontaminated fish group.

\section{Materials and methods}

\subsection{Experimental animals}

Soles $(0.972 \pm 0.115 \mathrm{~kg})$ were collected by trawling a region of muddy substrate North of Ile de Ré (Bay of Biscay, France; Long $1^{\circ} 20^{\prime}$; Lat $46^{\circ} 12^{\prime}$ ). Upon arrival at the laboratory, fish were transferred to indoor tanks supplied with open-flow seawater (temperature $15-16{ }^{\circ} \mathrm{C}$; salinity 28-31\%o). They were allowed to acclimate to the laboratory conditions for 6 weeks under natural photoperiod while fed fresh mussel and oyster flesh. Animals were starved for $48 \mathrm{~h}$ prior to any experimental use or manipulation.

\subsection{Contamination protocol}

Following acclimation, fish were randomly distributed between 2 experimental groups. Fish from the first group $(n=8)$ were used as control and fish from the second group $(n=8)$ were 
exposed to number-2 fuel. The polycyclic aromatic hydrocarbon $(P A H)$ composition of this fuel was comparable to that transported by the tanker ERIKA (Mazéas and Budzinki, 2001), although differences existed, especially with regard to long-chain $P A H$. The bioavailability of $P A H$ in the current contamination protocol have been described elsewhere (Claireaux et al., 2004). Briefly, such contamination conditions resulted in a water $P A H$ concentration ([PAH]) of $39 \mathrm{ng} \mathrm{l}^{-1}$ (summed phenanthrene, fluoranthene, pyrene, benz(a)anthracene, chrysene + triphenylene, benzo(b)fluoranthene, benzo(j)fluoranthene benzo(k)fluoranthene, benzo(a)pyrene, dibenz(a,h)anthracene $+\operatorname{dibenz}(\mathrm{a}, \mathrm{c})$ anthracene, benzo(g,h,i)perylene, indeno(1,2,3-cd)pyrene), a 4 fold increase in ethoxyresorufin- $O$-deethylase (EROD) activity, a 12 fold increase in white muscle [PAH] (8 to $92 \mathrm{ng} \mathrm{g}^{-1}$ dry tissues) and 6 fold increase in liver [PAH] (15 to $71 \mathrm{ng} \mathrm{g}^{-1}$ dry tissues).

Exposure to fuel was performed in $500 \mathrm{~L}$ rearing tanks covered with a polyethylene lining topped with $2 \mathrm{~cm}$ of sand. Typically, exposition lasted 5 days and 2 fish were exposed simultaneously. During that period, the water was not renewed and fish were not fed. The tested fuel to water ratio (1/200 vol of fuel/vol of water) was obtained by directly adding fuel onto the surface of the experimental tank. A gentle air bubbling allowed the aeration of the water and the homogeneity of the soluble phase. There was no direct contact between the fish in the sand and the fuel floating at the surface, although contamination via micro-particles cannot be totally dismissed. Following the 5-day exposure, pairs of fish were transferred to a tank containing unpolluted water and were left undisturbed for 24 hours. Reference control fish (group 1) were submitted to the same protocol except that they were not put in contact with fuel.

\subsection{Surgical procedure}


2 Following the $24 \mathrm{~h}$ post-exposure recovery period, fish were anaesthetised by immersion in an aqueous solution of ethyl-m-aminobenzoate (MS-222, $\left.0.1 \mathrm{mg} \mathrm{L}^{-1}\right)$. They were then weighed and placed on an operation table. During surgery fish were maintained under anaesthesia by irrigating the gills continuously with a $0.05 \mathrm{mg} \mathrm{L}^{-1}$ solution of MS-222. The ventral aorta was exposed via a 5-7 mm incision in the cleithrum. A cuff-type Transonic flow probe (Transonic

\subsection{Respirometry}

A complete description of the experimental set-up can be found in Lefrançois and Claireaux (2003). Briefly, the respirometry set-up was situated in a thermoregulated room $\left(15^{\circ} \mathrm{C}\right)$. Two respirometers $(24 \mathrm{~L})$ were used in parallel. They were submersed in a larger tank where water oxygenation was maintained at a normoxic level using a counter-current gas equilibration column bubbled with air. The respirometers were supplied with water from the outer tank at a flow rate of 2-3 $\mathrm{L} \mathrm{min}^{-1}$ via a pump. Oxygen concentration in the respirometers was measured using oxygen probes (Orbisphere Laboratories 27141) connected to a multichannel oxygen measuring system (Orbisphere Laboratories 2610) and a home-made data acquisition system (G. Guillou, CREMA-L'Houmeau). To measure dissolved oxygen concentration, water was pumped out of the respirometers and brought back into it after flowing over the oxygen electrodes. Fish oxygen consumption was estimated by sealing the respirometer (shutting 
1 water flow into the respirometers) and measuring the decrease in dissolved oxygen

concentration over $20 \mathrm{~min}$. Respirometers were then flushed until the next measurements. Oxygen probes were calibrated daily.

\subsection{Experimental protocol}

Following the 24 h-post surgery recovery period, oxygen consumption and cardiac variables were measured at the acclimation temperature $\left(15^{\circ} \mathrm{C}\right)$ during one hour. The water reservoir supplying the respirometer was then heated at a rate of $1.5^{\circ} \mathrm{C} \mathrm{h}^{-1}$. When water temperature reached $20{ }^{\circ} \mathrm{C}$ it was stabilised and oxygen consumption and cardiac output were monitored simultaneously during 20 to $30 \mathrm{~min}$. The same procedure was repeated at 25 and $30{ }^{\circ} \mathrm{C}$. At the end of the trial water temperature was brought back down to $15{ }^{\circ} \mathrm{C}$ and fish were allowed to recover overnight at this temperature.

\subsection{Calculation of oxygen consumption}

Oxygen consumption ( $\mathrm{mg} \mathrm{O}_{2} \mathrm{~kg}^{-1} \mathrm{~h}^{-1}$ ) was calculated using the following formula:

$$
\dot{M} O_{2}=\Delta \mathrm{C}_{\mathrm{w}} \mathrm{O}_{2} \times \Delta \mathrm{t}^{-1} \times \mathrm{VOL}_{\mathrm{resp}} \times \mathrm{M}^{-1}
$$

where $\Delta \mathrm{C}_{\mathrm{w}} \mathrm{O}_{2}$ is the change in water oxygen concentration $\left(\mathrm{mg} \mathrm{L}^{-1}\right), \Delta \mathrm{t}$ the measuring time (h), $\mathrm{VOL}_{\text {resp }}$ is the volume of the respirometer minus the volume of the fish (L), and $\mathrm{M}$ is the mass of the fish $(\mathrm{kg})$. 
1 To compare our oxygen consumption with previous reports, values of $\mathrm{MO}_{2}$ were 2 standardised to a body mass of $100 \mathrm{~g}$ using the following formula below (Schurmann and 3 Steffensen, 1997):

$$
M O_{2} \text { cor }=M O_{2 \text { meas }} \times\left(\mathrm{M}_{\text {meas }} \times \mathrm{M}_{\text {cor }}{ }^{-1}\right)^{1-\mathrm{A}}
$$

7 Where $M O_{2}$ cor $\left(\mathrm{mg} \mathrm{O}_{2} \mathrm{~kg}^{-1} \mathrm{~h}^{-1}\right)$ is the mass specific $M O_{2}$ of a fish weighing $\mathrm{M}_{\text {cor }}(=0.1 \mathrm{~kg})$,

$8 \quad M O_{2}$ meas $\left(\mathrm{mg} \mathrm{O}_{2} \mathrm{~kg}^{-1} \mathrm{~h}^{-1}\right)$ the mass specific $M O_{2}$ measured, and $\mathrm{M}_{\text {meas }}(\mathrm{kg})$ the mass of the

Background oxygen consumption by micro-organisms was routinely assessed by recording the oxygen consumption of an empty respirometer.

\subsection{Measurements of cardiac variables}

Cardiac output $(Q)$ was recorded at $20 \mathrm{~Hz}$ by connecting the flow probe to a Transonic flow meter (T206, Transonic Systems, Ithaca, NY, USA). Heart rate (HR) and stroke volume (SV) were calculated for each $8 \mathrm{~s}$ of recording and an average value for each $\mathrm{MO}_{2}$-recording period was calculated for each parameter.

\subsection{Data analysis and statistics}


1 Statistical analyses were conducted using STATGRAPHIC PLUS version 5.1. Statistical

comparisons were carried out using parametric analysis of variance for repeated measures followed with post hoc Tukey test. The effect of fuel exposure and temperature on fish oxygen consumption, cardiac output, heart rate and stroke volume was estimated using multiway ANOVA. The difference between control and contaminated fish in the effect of temperature upon oxygen consumption, cardiac output, heart rate and stroke volume was tested using one-way ANOVA. Data are presented as means \pm SEM.

\section{Results}

\subsection{Oxygen consumption}

Both temperature $(P<0.001)$ and exposure to fuel $(P<0.005)$ had a significant effect upon fish oxygen consumption $\left(M \mathrm{O}_{2}\right)$. In control fish at $15{ }^{\circ} \mathrm{C}$, resting $\mathrm{MO}_{2}$ was $60.60 \pm 5.28$ $\mathrm{mg} \mathrm{kg}^{-1} \mathrm{~h}^{-1}$ (Fig. 1A). With the increase in temperature, $M O_{2}$ increased until it reached a maximum value at $25{ }^{\circ} \mathrm{C}\left(119.29 \pm 5.59 \mathrm{mg} \mathrm{kg}^{-1} \mathrm{~h}^{-1}\right)$. At $30{ }^{\circ} \mathrm{C}$, on the other hand, the trend was reversed and $\dot{M} O_{2}$ decreased to $100.17 \pm 10.63 \mathrm{mg} \mathrm{kg}^{-1} \mathrm{~h}^{-1}$.

At $15^{\circ} \mathrm{C}$, resting $\mathrm{M} \mathrm{O}_{2}$ of fuel-exposed sole was significantly lower than that of control fish $\left(44.83 \pm 4.36 \mathrm{mg} \mathrm{kg}^{-1} \mathrm{~h}^{-1} ; P=0.046\right)$. As for the control group, oxygen consumption of fuelexposed sole increased significantly with increasing temperature until it reached a maximum of $94.82 \pm 4.45 \mathrm{mg} \mathrm{kg}^{-1} \mathrm{~h}^{-1}$ at $25^{\circ} \mathrm{C}$. At $30^{\circ} \mathrm{C}, M O_{2}$ dropped to $86.73 \pm 9.67 \mathrm{mg} \mathrm{kg}^{-1} \mathrm{~h}^{-1}$. 


\subsection{Cardiac variables}

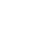

Cardiac output $(\dot{Q})$, heart rate $(H R)$ and stroke volume $(S V)$ were influenced by temperature $(P<0.02,0.001$ and 0.003 respectively $)$ and exposure to hydrocarbons $(P<0.002,0.04$ and 0.01 respectively). Cardiac output, heart rate and stroke volume of control fish at $15{ }^{\circ} \mathrm{C}$ were $22.04 \pm 1.59 \mathrm{ml} \mathrm{min}^{-1} \mathrm{~kg}^{-1}, 40 \pm 3.41$ beats $\min ^{-1}$ and $0.57 \pm 0.04 \mathrm{ml} \mathrm{kg}^{-1}$ respectively (Fig.

1B,C and D respectively). With the increase in temperature, $Q$ and $H R$ increased to a maximum at $25^{\circ} \mathrm{C}\left(30.84 \pm 2.86 \mathrm{ml} \mathrm{min}^{-1} \mathrm{~kg}^{-1}\right.$ and $70 \pm 5.07$ beats $\min ^{-1}$ respectively). Over the same temperature range, stroke volume displayed a mirror image with a minimum value of $0.46 \pm 0.06 \mathrm{ml} \mathrm{kg}{ }^{-1}$ at $25^{\circ} \mathrm{C}$. At $30{ }^{\circ} \mathrm{C}$, both $\dot{Q}$ and HR dropped $\left(20.25 \pm 1.90 \mathrm{ml} \mathrm{min}^{-1} \mathrm{~kg}^{-}\right.$ ${ }^{1}$ and $39 \pm 3.47$ beats $\min ^{-1}$ respectively) and were then not statistically different from the values recorded at $15{ }^{\circ} \mathrm{C}$. Meanwhile, $S V$ increased $\left(0.51 \pm 0.07 \mathrm{ml} \mathrm{kg}^{-1}\right)$ to the level initially reported at $15^{\circ} \mathrm{C}$.

When compared to the control group, fuel-exposed fish at $15{ }^{\circ} \mathrm{C}$ displayed significantly altered $\dot{Q}\left(17.20 \pm 1.58 \mathrm{ml} \mathrm{min}{ }^{-1} \mathrm{~kg}^{-1} ; P=0.002\right)$ and $S V\left(0.46 \pm 0.04 \mathrm{ml} \mathrm{kg}^{-1} ; P=0.0021\right)$ but not $H R\left(37 \pm 3.76\right.$ beats $\left.\min ^{-1} ; P>0.05\right)$. Moreover, contrary to what was found in control fish, cardiac output of fuel-exposed fish did not change significantly with the increase in temperature. On the other hand, $H R$ increased significantly until a maximum value was reached at $25{ }^{\circ} \mathrm{C}\left(58.0 \pm 10.76\right.$ beats $\left.\min ^{-1}\right)$. Between 25 and $30^{\circ} \mathrm{C}$ a sharp decrease was observed $\left(27 \pm 3.14\right.$ beats $\left.\min ^{-1}\right)$. These changes in $H R$ were mirrored by changes in $S V$ which followed U-shape response curve with a minimum value at $25^{\circ} \mathrm{C}\left(0.35 \pm 0.05 \mathrm{ml} \mathrm{kg}^{-1}\right)$.

\section{Discussion}


2 The objective of the present study was to examine the impact of hydrocarbon exposure upon the cardio-respiratory performance of the common sole. This performance was assessed by

submitting $15{ }^{\circ} \mathrm{C}$-acclimated, experimental fish to an acute increase in temperature $\left(15{ }^{\circ} \mathrm{C}\right.$ at a rate of $\left.1.5{ }^{\circ} \mathrm{C} \mathrm{h}^{-1}\right)$. By comparing oil-exposed and uncontaminated fish groups, we investigated how exposure to number- 2 oil altered the capacity of the cardio-respiratory system to sustain a temperature-driven increase in tissues metabolic demand. Experimental results were analysed under the assumption that weakened cardio-respiratory performance meant impaired adaptive abilities (e.g., Sartoris et al., 2003; Lanning et al., 2004).

\subsection{Cardiac function and metabolism of sole under reference conditions.}

Our experimental results provide information about the cardiovascular physiology and metabolism of a poorly studied species. Oxygen consumption of resting, uncontaminated, 15 ${ }^{\circ} \mathrm{C}$-acclimated sole was relatively high $\left(60 \mathrm{mg} \mathrm{kg}^{-1} \mathrm{~h}^{-1}\right)$. Because fish were left undisturbed during this phase of the experiment, we initially considered that this oxygen demand was representative of sole basal metabolic rate $(S M R)$. However, the comparison with resting $M \mathrm{O}_{2}$ values reported in a preceding study $\left(39 \mathrm{mg} \mathrm{kg}^{-1} \mathrm{~h}^{-1}\right.$; Davoodi and Claireaux, 2007) highlighted a $36 \%$ difference between the two values. We have no satisfactory explanation for this discrepancy but it can be hypothesized that, although fish were allowed a 24-hour recovery period following the surgical implantation of the flow probes, a certain degree of trauma may have persisted, resulting in a supplementary oxygen demand. Our values for SMR are also higher than the values reported by Lefrançois and Claireaux (2003). These authors estimated SMR of a $100 \mathrm{~g}$ common sole to be $32 \mathrm{mg} \mathrm{kg}^{-1} \mathrm{~h}^{-1}$ at $16{ }^{\circ} \mathrm{C}$. Van den Thillart et al., (1994) reported SMR of a $100 \mathrm{~g}$ common sole to be $41 \mathrm{mg} \mathrm{kg}^{-1} \mathrm{~h}^{-1}$ at $20^{\circ} \mathrm{C}$. 
2 Cardiac output in control sole at $15{ }^{\circ} \mathrm{C}$ was approximately $22 \mathrm{ml} \mathrm{min}^{-1} \mathrm{~kg}^{-1}$. To our knowledge there are no other published measurements of cardiac output in sole. However, measurements of cardiac output in other benthic, poorly active fish species have been

5

reported. In $10{ }^{\circ} \mathrm{C}$-acclimated lingcod (Ophiodon elongates) a resting $\dot{Q}$ of $11 \mathrm{ml} \mathrm{min}{ }^{-1} \mathrm{~kg}^{-1}$ was reported by Farrell (1982). Axelsson et al. (1989) measured a resting $\dot{Q}$ of nearly $19 \mathrm{ml}$ $\min ^{-1} \mathrm{~kg}^{-1}$ in $12^{\circ} \mathrm{C}$-acclimated sea raven (Hemitripterus americanus).

Resting heart rate and stroke volume in $15{ }^{\circ} \mathrm{C}$ acclimated uncontaminated sole were 40 beats $\min ^{-1}$ and $0.57 \mathrm{ml} \mathrm{kg}^{-1}$ respectively. Sureau and Lagardère (1991) telemetered the heart rate of free swimming sole under natural conditions (water temperature fluctuating between 8 and 12 ${ }^{\circ} \mathrm{C}$ ). They reported a resting heart beat frequency ranging from 24 to 31 beats $\min ^{-1}$ and a maximum (active) heart rate of about 50 beats $\min ^{-1}$. Also using telemetry, Lefrançois and Claireaux (2003), estimated the active heart rate of a $16^{\circ} \mathrm{C}$-acclimated sole at 60 beats $\mathrm{min}^{-1}$. Despite quite different measuring technique and experimental protocol, the heart rate values we obtained fit reasonably well within that range.

\subsection{Acute temperature change}

Figure 2 is an attempt to combine the current work with two previous studies which also investigated the effect of temperature upon metabolism of sole. The thick solid line represents the relationship between acclimation temperature and maximum metabolic rate during aerobic activity $(A M R)$ established by Lefrançois and Claireaux (2003). The thick dotted line is a hypothetical relationship between $A M R$ and acclimation temperature in oil-exposed sole. This relationship was established by shifting the previous relationship downward. The anchor point 
1 (black dot) corresponds to the $A M R$ of a $15{ }^{\circ} \mathrm{C}$-acclimated, oil-exposed sole (Davoodi and

2 Claireaux, 2007). The thin solid and dotted lines were redrawn from Fig. 1 and represent the

relationships between resting $\mathrm{MO}_{2}$ and temperature in control and fuel exposed groups respectively. As temperature approaches the species' upper incipient lethal temperature (UILT $\sim 27{ }^{\circ} \mathrm{C}$; Lefrançois and Claireaux, 2003) a convergence of the curves is readily noticed both for the oil-exposed and uncontaminated scenarios. This suggests that whether sole are acclimated (thick lines) or acutely exposed (thin lines) to supra optimal temperature they are eventually faced with similar metabolic limitations (see also Lee et al., 2003; Gollock et al., 2006). As a result, at the vicinity of the UILT resting $M O_{2}$ (thin lines) tend to equal $A M R$ (thick lines) meaning that aerobic metabolic scope is close to nil. In such conditions, fish are unable to face any supplementary metabolic demand and long-term survival is evidently impaired.

The causes of the reduced metabolic performance at high temperature are many and they have received considerable attention (e.g., Brett, 1971; Taylor et al., 1997; Farrell, 1997, 2007; Pörtner, 2002; Gollock et al., 2006; Pörtner and Knust, 2007). Our experimental results suggest that decreased cardiovascular performance is most likely involved. There are very few reports documenting the cardiac response of fish to an acute temperature increase. For instance, in $5{ }^{\circ} \mathrm{C}$-acclimated winter flounder (Pseudopleuronectes americanus) Cech et al. (1976) showed that raising the temperature to $10{ }^{\circ} \mathrm{C}$ was associated with an increase in cardiac output (from 16 to $20 \mathrm{ml} \mathrm{min}^{-1} \mathrm{~kg}^{-1}$ ). As for the sole, these changes in $\dot{Q}$ were attributed to increased heart rate (30 to 48 beats $\mathrm{min}^{-1}$ ) associated with a slightly decreased stroke volume $\left(0.55\right.$ to $\left.0.42 \mathrm{ml} \mathrm{kg}^{-1}\right)$. When a $5{ }^{\circ} \mathrm{C}$ temperature increase was applied to $10{ }^{\circ} \mathrm{C}$ acclimated winter flounder, the same trend persisted with $Q$ and $H R$ rising from 23 to $36 \mathrm{ml}$ 
$1 \min ^{-1} \mathrm{~kg}^{-1}$ and from 35 to 62 beats $\min ^{-1}$ respectively. Meanwhile, $S V$ dropped from 0.68 to

$20.60 \mathrm{ml} \mathrm{kg}^{-1}$ (Cech et al., 1976). Gollock et al. (2006) investigated the cardiovascular and metabolic response of Atlantic cod (Gadus morhua) as water temperature was raised from 10 to $24{ }^{\circ} \mathrm{C}$ in approximately 8 hours. Their observations are similar to ours, although differences must be noted. Both in cod and sole the rapid increase in water temperature was associated with increased $\mathrm{MO}_{2}, Q$ and $H R$. However, the slopes of the temperature-response curves were quite different i.e., in cod $\mathrm{Q}_{10}$ were $2.78,2.48$ and 2.12 whereas in sole $\mathrm{Q}_{10}$ were 1.97, 1.41 and 1.77 respectively. The $S V$ versus temperature relationships were also quite different. Whereas in cod $S V$ was generally maintained across the temperature range, in sole, on the other hand, $S V$ followed a U-shape pattern that mirrored the $H R$ response curve. One other difference between cod and sole relates to the $\mathrm{MO}_{2}$ versus $\dot{Q}$ relationship. Whereas in cod $M \mathrm{O}_{2}$ increased directly with $\dot{Q}$ (Gollock et al., 2006), in sole, on the other hand, a 2-phase response was observed (Fig. 3; open boxes). Between 15 and $25{ }^{\circ} \mathrm{C}$, the rise in $M O_{2}$ was tightly coupled to the rising $Q$. Above $25^{\circ} \mathrm{C}$, however, a rather sharp $(\sim 30 \%)$ decrease in cardiac output was observed, which was associated with a relatively modest $(\sim 15 \%)$ reduction in metabolic oxygen demand. This relative uncoupling of $\dot{M} O_{2}$ and $\dot{Q}$ suggests that at supra-optimal temperature, oxygen demand of sole relied on enhanced $\mathrm{O}_{2}$ extraction from the blood and that internal oxygen stores were being depleted. Using Fick's principles it can be calculated that arterio-venous difference in $\mathrm{O}_{2}$ content $\left(\Delta \mathrm{O}_{2 a-v}\right)$ increased nearly 2 fold between 15 and $30{ }^{\circ} \mathrm{C}$. If one considers that arterial blood leaving the gills has an oxygen partial pressure close to that of ambient water, and that between 15 and $30{ }^{\circ} \mathrm{C}$ water $\mathrm{O}_{2}$ solubility dropped $30 \%$, it is most likely that the observed increased $\Delta O_{2 a-v}$ was not due to increased diffusion at the gill but was rather due to increased extraction from the blood. One 
corollary to the declining venous oxygen content is, however, that the myocardium working ability was probably affected (Farrell, 2007). The heart is a terminal organ in fish circulation and because of poor coronary circulation, fish myocardial oxygen supply heavily relies upon venous blood $\mathrm{O}_{2}$ content (Davie and Farrell 1991). The increased recourse to oxygen stores and the associated drop in venous blood oxygen content possibly contributed to the rapid decline in cardiac output at temperature above $25^{\circ} \mathrm{C}$ (Fig.3).

\subsection{Oil-exposure}

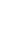

Globally, exposure to number-2 oil resulted in lower $M O_{2}, \dot{Q}, H R$ and $S V$ and, except for cardiac output, all variables displayed a response pattern to increasing temperature that was similar to control (Fig. 1). The most striking consequence of fuel exposure was the lessened ability of the cardio-respiratory system to maintain internal oxygen flow (Fig. 3; solid boxes).

Under acclimation condition $\left(15{ }^{\circ} \mathrm{C}\right)$ fuel-exposed fish displayed lower $\dot{M} O_{2}$ and $\dot{Q}$ but those values positioned adequately onto the relation established under control condition (Fig.3; grey line). As soon as temperature rose, however, departure from the control situation was observed. This deviation was minor at $20{ }^{\circ} \mathrm{C}$ but it became statistically significant at 25 and $30{ }^{\circ} \mathrm{C}$. This premature uncoupling of $\mathrm{MO}_{2}$ from $\dot{Q}$ suggests that fuel-exposed fish were rapidly unable to sustain the temperature-driven increase in tissues oxygen demand. As a result, venous oxygen stores were mobilized early on during the thermal challenge, with the consequence that the reduced venous blood oxygen content imposed a supplementary burden to the myocardium working ability. 
1 Because published data on the effect of oil-exposure upon fish cardio-respiratory function are

2 lacking, we can only speculate about the possible mechanisms involved in the impaired ability of the heart to respond to increased metabolic demand. Possible explanations include, alteration in pacemaker cell activity and action potential shape, decreased adrenergic sensitivity of the myocardium, reduced ability of the myocytes to mobilized $\mathrm{Ca}^{+2}$ during excitation-contraction coupling (Hartzell, 1988) or altered regulation of central venous pressure (Zhang et al., 1998; Sandblom et al., 2005, 2006). The cardiotoxic effects of petrogenic PAH have been the subject of specific studies. These studies suggest the existence of a high affinity target involved in the electrophysiology of the myocardium (Incardona et al., 2004 and 2009). However, the precise target and mechanism remain elusive and quite clearly investigation of the effect of fuel exposure upon processes that contribute to the contractility of fish myocardium is an avenue for future research.

\section{Conclusion}

The present work revealed that exposure to number- 2 oil affected the metabolism and cardiac function of sole. A well-functioning heart is vital for providing sufficient oxygen and nutrients to the tissues and for removing metabolic wastes. It is also essential to mobilise energy in response to acute or chronic challenges from the environment. Our previous studies (Claireaux et al., 2004; Davoodi and Claireaux, 2007; Gillier et al., 2009) demonstrated that fuel-exposure that mimicked the conditions created by the ERIKA oil spill resulted in impaired fitness (growth and survival) and ability to tolerate an episode of reduced oxygen availability. The present work strengthened these earlier studies by revealing that the lessened ecological performance can be explained, at least partially, by lessened functional integrity of the cardio-respiratory system. 


\section{Acknowledgements:}

3 We would like to thank D.J. McKenzie for his comments on an earlier version of this

4 manuscript, as well as G. Guillou, M. Guillaut, P. Pineau, D. Leguay and M. Prineau for their

5 technical assistance. We also wish to acknowledge the help of the crew of the R/V "Gwen

6 Drez", Y. Desaunay (Ifremer) and J.-M. Arruabarrena who kindly collected the fish. The

7 current research was funded by "Ministère Français de l'Écologie et du Développement

8 Durable" as part of the program "Suivi des conséquences écologiques et écotoxicologiques de

9 la marée noire due au naufrage de l'Erika". The support of the scientific committee in charge

10 of the program is sincerely acknowledged as well as the help of the "Centre de

11 Documentation de Recherche et d'Expérimentations sur les pollutions accidentelles des

12 Eaux". All experimental procedures in this work comply with the current French laws. 


\section{References}

Anderson J.W., Dixit D.B., Ward G.S., Foster R.S., 1977. Effects of petroleum hydrocarbons on the rate of heart beat and hatching success of estuarine fish embryos. In: Vernberg F.J., Calabrese A., Thurberg F.P., Vernberg W.B. (Eds), Physiological responses of marine biota to pollutants. Academic press, New York, London, pp 95-114.

Axelsson M., Driedzic W.R., Farrell A.P., Nilsson S., 1989. Regulation of cardiac output and gut blood flow in the sea raven Hemitripterus americanus. Fish Physiol. Biochem. 6, 315326.

Brett, J.R., 1971. Energetic responses of salmon to temperature. A study of some thermal relations in the physiology and freshwater ecology of sockeye salmon (Oncorhynchus nerka). Amer. Zool. 11, 99-113.

Carls M.G., Rice S.D., Hose J.E., 1999. Sensitivity of fish embryos to weathered crude oil: part I. Low level exposure during incubation causes malformations, genetic damage, and mortality in larval Pacific herring (Clupea pallasi). Environ. Toxicol. Chem. 18, 481-493.

Cech J.J., Bridges D.W., Rowell D.M., Balzer P.J., 1976. Cardiovascular responses of winter flounder, Pseudopleuronectes americanus, to acute temperature increase. Can. J. Zool. 54, $1383-1388$.

Claireaux, G., Désaunay, Y., Akcha, F., Aupérin, B., Bocquené, G., Budzinski, H., Cravedi, J.-P., Davoodi, F., Galois, R., Gilliers, C., Goanvec, C., Guérault, D., Imbert, N., Mazéas, O., Nonnotte, G., Nonnotte, L., Prunet, P., Sebert P. and Véttier A., 2004. Influence of oil exposure on the physiology and ecology of the common sole Solea solea (L.): experimental and field approaches. Aquat. Living Resour. 17: 335-352.

Clark, R.C., MacLeod, W.D., 1977. Inputs, transport mechanisms and observed concentrations of petroleum in the marine environment. In: Malin, D.C. (Ed), Effects of 
petroleum on Arctic and Subarctic marine environment and organisms. Academic press New York., Vol 1, pp 91-224.

Davie, P.S., Farrell A.P., 1991. The coronary and luminal circulations of the myocardium of fishes. Can. J. Zool. 69, 1993-2001.

Davoodi, F., Claireaux, G., 2007. Effects of exposure to petroleum hydrocarbons upon the metabolism of the common sole Solea solea. Mar. Poll. Bull. 54, 928-934.

Farrell, A.P., 1982. Cardiovascular changes in the unanaesthetized lingcod (Ophiodon elongatus) during short-term, progressive hypoxia and spontaneous activity. Can. J. Zool. 60, 933-941.

Farrell, A.P., 1997. Effects of temperature on cardiovascular performance. In: Wood, C.M., McDonald, D.G. (Eds), Global Warming Implications for Freshwater and Marine Fish. Cambridge University Press, Cambridge, pp. 135-158.

Farrell, A.P., 2007. Cardiorespiratory performance during prolonged swimming tests with salmonids: a perspective on temperature effects and potential analytical pitfalls. Phil. Trans. Roy. Soc. 362, 2017-2030.

Gilliers, C., Loizeau, V., Galois, R., Claireaux, G., Le Pape, O., 2009. Influence of short term exposure to hydrocarbons on mid term survival, growth and energy storage of juvenile common sole (Solea solea L.): a mesocosm experiment. Mar. Environ. Res. Submitted.

Gollock, M.J., Currie, S., Petersen, L.H., Gamperl, A.K., 2006. Cardiovascular and haematological responses of Atlantic cod (Gadus morhua) to acute temperature increase. J. Exp. Biol. 209, 2961-2970.

Halpern, B.S., Walbridge, S., Selkoe, K.A., Kappel, C.V., Micheli, F., D’Agrosa, C., Bruno, J. Casey, K.S., Ebert, C., Fox, H.E., Fujita, R., Heinemann, D., Lenihan, H.S., Madin, E.M.P., Perry, M., Selig, E.R., Spalding, M., Steneck, R., Watson, R., 2008. A Global Map of Human Impact on Marine Ecosystems. Science 319, 948-952. 
1 Hay, J., Thébaud O., 2006. Including ecological damage in the monetary valuation of spill impacts: an assessment of current practice. Océanis 32, 297-319.

Hay, J., Treper, S., 2006. Economic assessment and compensation for ecological damage caused by oil spills. An overview of the various approaches. Océanis 32, 267-278.

Hartzell, H.C., 1988. Regulation of cardiac ion channels by catecholamines, actylcholine and second messenger systems. Prog. Biophys. Molec. Biol. 52, 165-247.

Henry T.R., Spitsbergen J.M., Hornung M.W., Abent C.C., Peterson R.E., 1997. Early life stage toxicity of 2,3,7,8-tetrachlorodibenzo-p-dioxin in Zebrafish (Danio rerio). Toxicol. Appl. Pharmacol. 142, 56-98.

Incardona, J.P., Collier, T.K., Scholz, N.L., 2004. Defects in cardiac function precede morphological abnormalities in fish embryos exposed to polycyclic aromatic hydrocarbons. Toxicol. Appl. Pharmacol. 196, 191-205.

Incardona, J., Carls, M.G., Day, H.L., Sloan, C.A., Bolton, J.L., Collier, T.K., Scholz, N.L., 2009. Cardiac arrhythmia is the primary response of embryonic Pacific herring (Clupea pallasi) exposed to crude oil during weathering. Environ. Sci. Technol. 43, 201-207.

Lanning, G., Bock, C., Sartoris, F.J., Pörtner, H.O., 2004. Oxygen limitation of thermal tolerance in cod, Gadus morhua L., studied by magnetic resonance imaging and on line venous oxygen monitoring. Amer. J. Physiol. 287, R902-R910.

Lee, C. G., Farrell, A. P., Lotto, A., MacNutt, M. J., Hich, S. G., Healey, M. C., 2003. The effect of temperature on swimming performance and oxygen consumption in adult sockeye (Oncorhynchus nerka) and coho (O. kisutch) salmon stocks. J. Exp. Biol. 206, 3239-3251.

Lefrançois C., Claireaux G., 2003. Influence of ambient oxygenation and temperature on metabolic scope and scope for heart rate in the common sole Solea solea. Mar. Ecol. Prog. Ser. 259, 273-284.

Lotka, A., 1922. Contribution to the energetics of evolution. P.N.A.S. 8, 147-151. 
1 Marty G.D., Hose J.E., McGurk M.D., Brown E.D., Hinton D.E., 1997. Histopathology and cytogenetic evaluation of Pacific herring larvae exposed to petroleum hydrocarbons in the laboratory or in Prince William Sound, Alaska, after the Exxon Valdez oil spill. Can. J. Fish. Aquat. Sci. 54, 1846-1857.

Mazéas L., Budzinki H., 2001. Improve accuracy of GC-MS quantification of aliphatic and aromatic hydrocarbons in marine sediments and petroleums. Validation on reference matrices and application to the Erika oil spill. Intern. J. Environ. Anal. Chem. 82, 157-173.

Middaugh D.P., Shelton M.E., McKenney C.L., Cherr G.N., Chapman P.J., Courtney L.A., 1998. Preliminary observations on responses of embryonic and larval Pacific herring, Clupea pallasi, to neutral fraction biodegradation products of weathered Alaska north slope oil. Arch. Environ. Contam. Toxicol. 34, 188-196.

Pörtner, H.O., 2002. Physiological basis of temperature-dependent biogeography: trade-offs in muscle design and performance in polar ectotherms. J. Exp. Biol. 205, 2217-2230.

Pörtner, H.O., Knust, R., 2007. Climate change affects marine fishes through the oxygen limitation of thermal Tolerance. Science 315, 95-97.

Sandblom E., Axelsson M., McKenzie D. J., 2006. Venous responses during exercise in rainbow trout, Oncorhynchus mykiss: $\alpha$-adrenergic control and the antihypotensive function of the renin-angiotensin system. Comp. Biochem. Physiol. 144, 401-409.

Sandblom E., Farrell A.P., Altimiras J., Axelsson M., Claireaux G., 2005. Cardiac preload and venous return in swimming sea bass (Dicentrarchus labrax L.). J. Exp. Biol. 208, 1927-1935.

Sartoris, F.J., Bock, C., Serendero, I., Lanning, G., Pörtner, H.O., 2003. Temperature dependant changes in energy metabolism, intracellular $\mathrm{pH}$ and blood venous rension in the Atlantic cod. J. Fish Biol. 62, 1239-1253. 
1 Schurmann H., Steffensen J.F., 1997. Effects of temperature, hypoxia and activity on the metabolism of juvenile Atlantic cod. J. Fish Biol. 50, 1166-1180.

Sureau D., Lagardère J.P., 1991. Coupling of heart rate and locomotor activity in sole, Solea solea, and bass, Dicentrarchus labrax in their natural environment by using ultrasonic telemetry. J. Fish Biol. 38, 399-405.

Taylor, E.W., Egginton, S., Taylor, S.E., Butler, P.J., 1997. Factors which may limit swimming performance at different temperature. In: Wood, C.M., McDonald, D.G. (Eds). Global Warming: Implications for Freshwater and Marine Fish. Society for Experimental Biology Seminar Series 61, Cambridge: Cambridge University Press, pp. 105-133.

Van Den Thillart G., Dalla Via J., Vitali G., Cortesi P., 1994. Influence of long-term hypoxia exposure on the energy metabolism of Solea solea. I. Critical $\mathrm{O}_{2}$ levels for aerobic and anaerobic metabolism. Mar. Ecol. Prog. Ser. 104, 109-117.

Vines C.A., Robbins T., Griffin F.J., Cherr G.N., 2000. The effects of diffusible creosotederived compounds on development in Pacific herring (Clupea pallasi). Aquat. Toxicol. $51,225-239$

Walker M.K., Spitsbergen J.M., Olson J.R., Peterson R.E., 1991. 2,3,7,8-tetrachlorodibenzop-dioxin (TCDD) toxicity during early life stage development of lake trout (Salvelinus namaycush). Can. J. Fish. Aquat. Sci. 48, 875-883.

Yamamoto K.I., 1992. Relationship of respiration to body weight in the tilapia Oreochromis niloticus under resting and normoxic conditions. Comp. Biochem. Physiol. 103, 81-83.

Zhang Y., Weaver L., Ibeawuchi A., Olson K.R., 1998. Catecholaminergic regulation of venous function in the rainbow trout. Amer. J. Physiol. 274, R1195-R1202. 


\section{$1 \quad$ Figure legends}

2 Figure 1: Effect of a 5-day exposure to number-2 oil upon the metabolic and cardiac responses of sole to a $15{ }^{\circ} \mathrm{C}$-acute temperature increase. A: oxygen consumption; B: cardiac

output; C: heart rate; D: stroke volume. Values are means \pm SEM. Open symbols: control, uncontaminated fish $(\mathrm{n}=8)$. Close symbols: oil-exposed fish $(\mathrm{n}=8)$. * denote statistically significant difference with the situation at $15{ }^{\circ} \mathrm{C}$. $\dagger$ indicate statistically significant difference between control and fuel-exposed groups.

Figure 2: Integrated view of the effect of water temperature on the metabolism of sole. Solid lines: uncontaminated control fish. Dotted lines: oil-exposed fish. Thick lines: active metabolic rate. Thin lines: routine metabolism. UILT: upper incipient lethal temperature (from Lefrançois and Claireaux, 2003). See text for more details

Figure 3: Relationship between metabolic rate and cardiac output in control, uncontaminated fish (open symbols) and in oil-exposed fish (closed symbols). Arrows indicate the course of the temperature increase from 15 to 20,25 and $30{ }^{\circ} \mathrm{C}$. The grey line is a regression using control fish data at 15,20 and $25^{\circ} \mathrm{C}\left(\dot{M} O_{2}=7.05 Q-99.19 ; \mathrm{R}^{2}=0.99\right)$. See text for further details. 
$1 \quad$ Figure 1

2
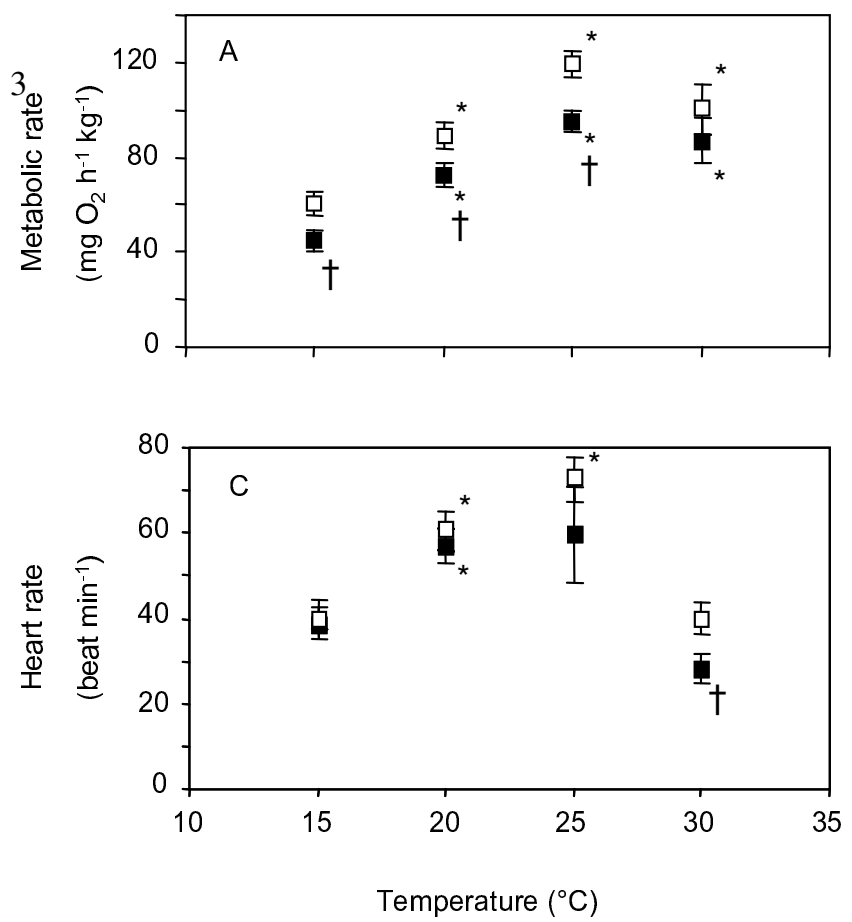
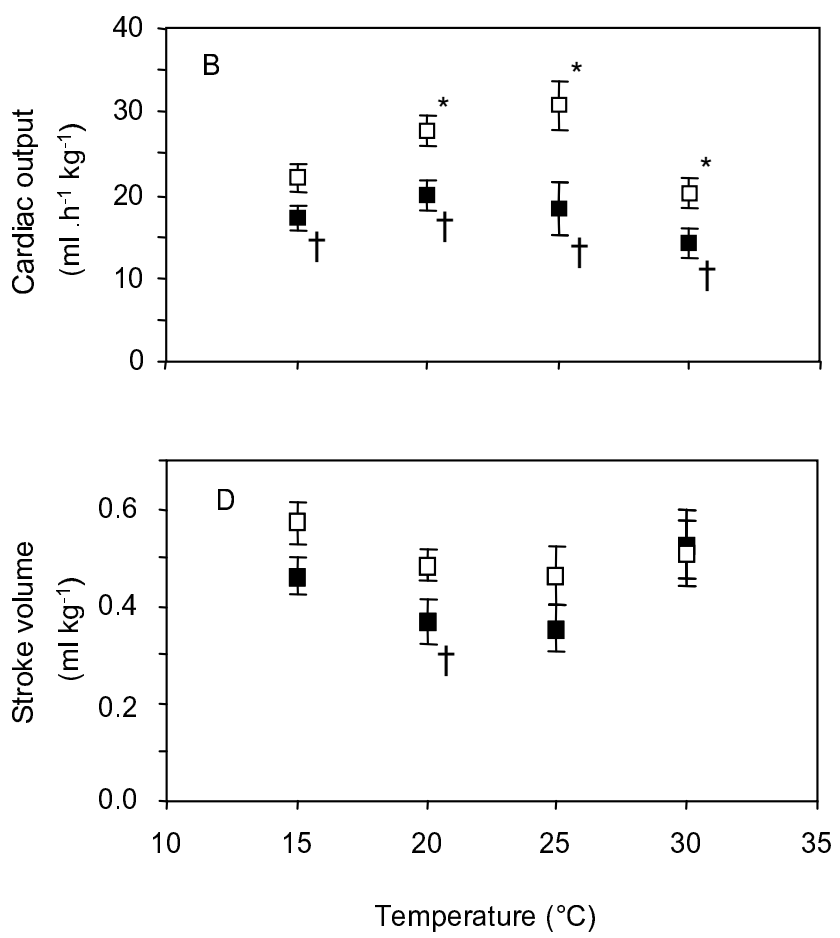
Figure 2

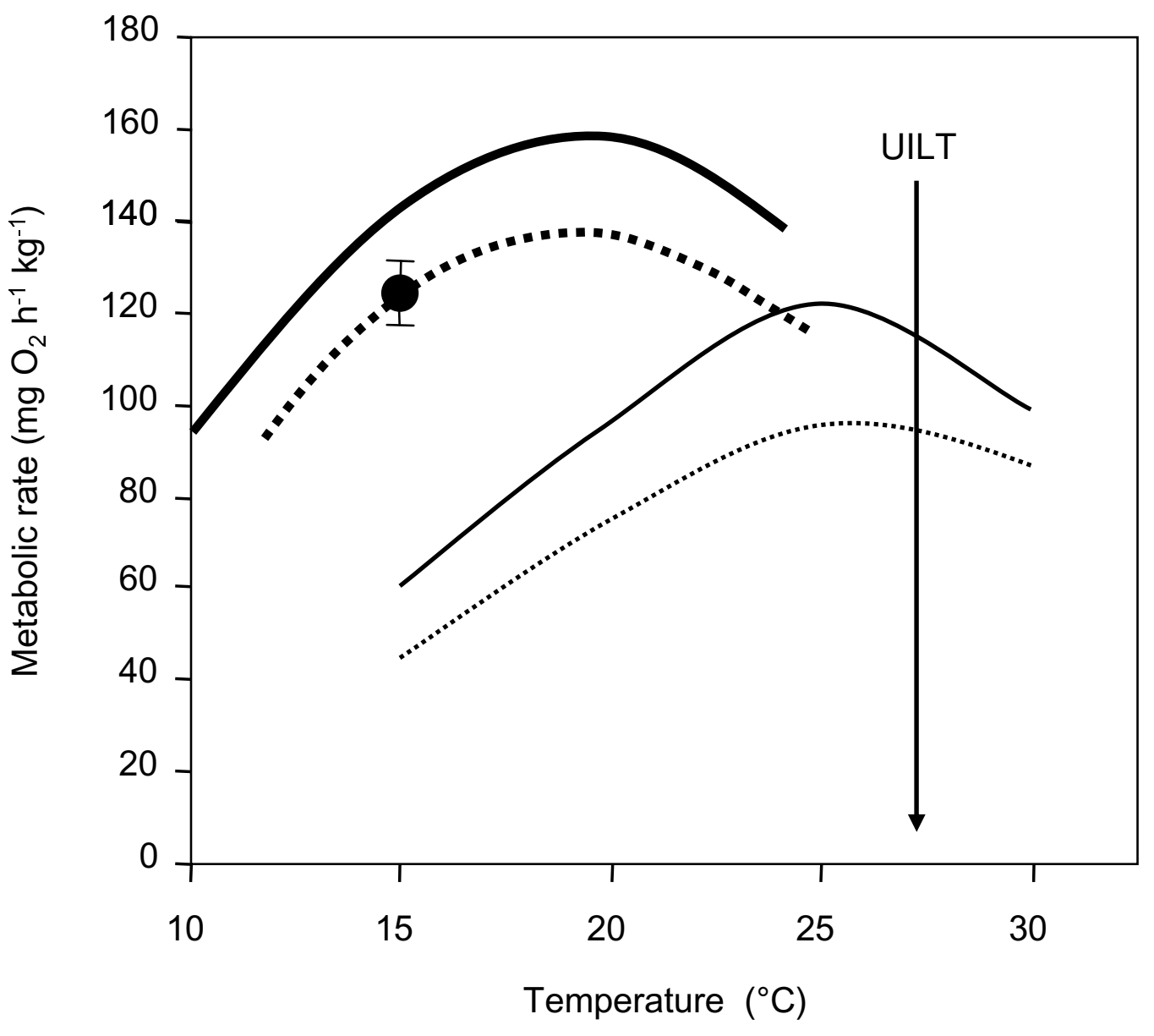


Figure 3

2

3

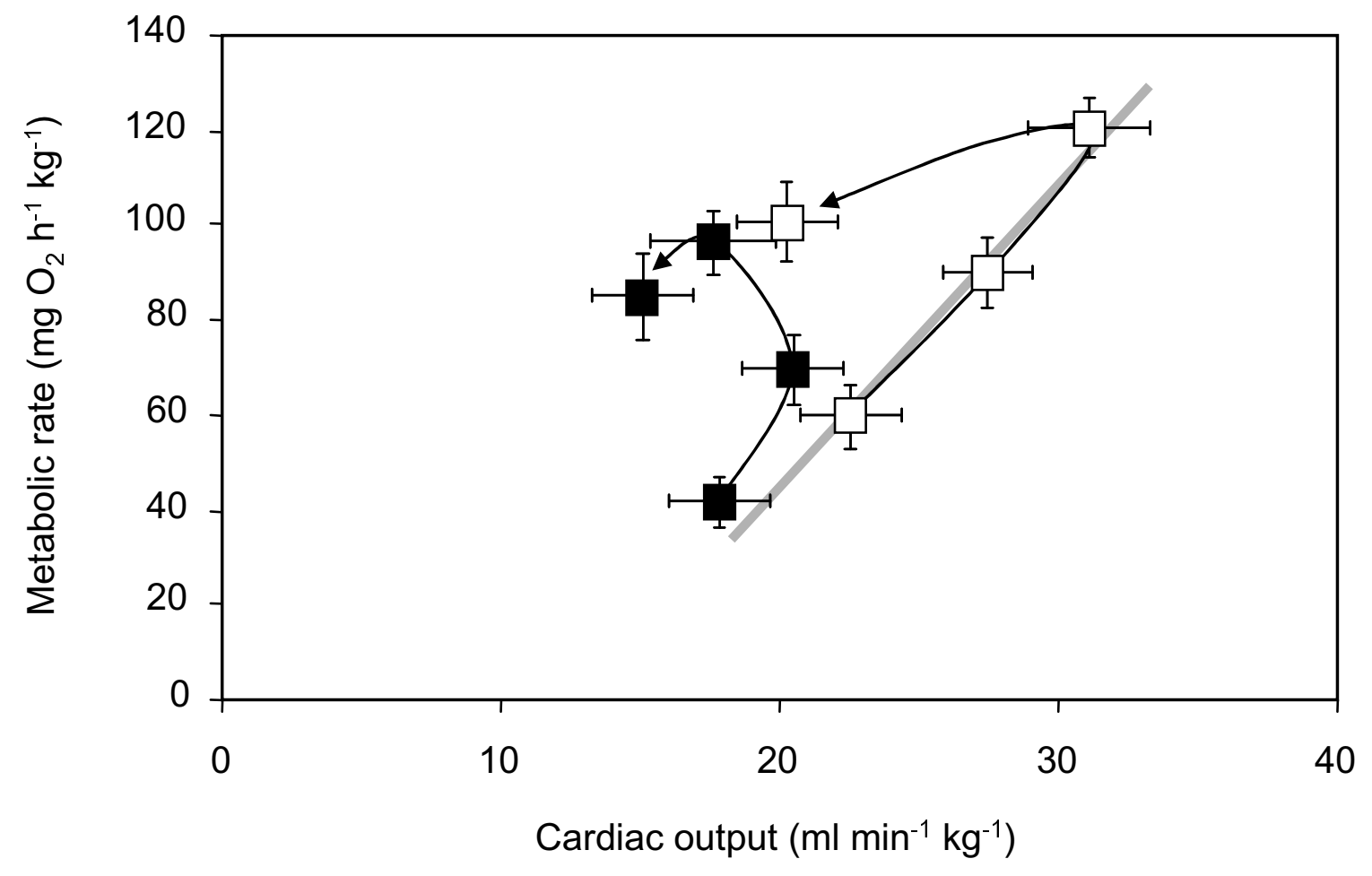

